\title{
The role of human papillomavirus in oncogenic transformation and its contribution to the etiology of precancerous lesions and cancer of the larynx: A review
}

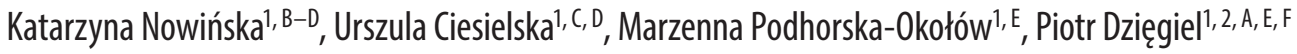 \\ ${ }^{1}$ Departament of Histology and Embriology, Wroclaw Medical University, Poland \\ ${ }^{2}$ Department of Physiotherapy, Wroclaw University School of Physical Education, Poland \\ A - research concept and design; $\mathrm{B}$ - collection and/or assembly of data; $\mathrm{C}$ - data analysis and interpretation; \\ $D$ - writing the article; $E$ - critical revision of the article; $F$ - final approval of article
}

Address for correspondence

Katarzyna Nowińska

E-mail: katarzyna.nowinska@onet.pl

Funding sources

None declared

Conflict of interest

None declared

Received on July 30, 2015

Revised on November 08, 2016

Accepted on December 01, 2016

\begin{abstract}
Human papillomavirus (HPV) belongs to the Papillomaviridae family and infects squamous cells and mucous membranes of humans. Various studies conducted over the last years have shown a correlation between HPV infection and carcinogenesis process. The DNA of the virus is detected in approximately $20 \%$ of cancers of the upper respiratory tract. The presence of HPV in cancerous lesion of the larynx varies depending on the procedure applied for sample collection and the viral DNA detection method. The high variance in the frequency of HPV detection is observed even among results obtained with the use of $P C R$ reaction. It varies between 3 and $85 \%$. HPV is also the etiological factor of laryngeal papillomas in both children and adults. However, a considerable amount of research demonstrates that 1-7\% of the larynx papillomas in adults undergo transformation into squamous cell carcinoma. The aim of the study was to summarize the current state of knowledge regarding the presence of the HPV virus in the larynx as well as its participation in malignant transformation.
\end{abstract}

Key words: human papillomavirus, larynx cancer, laryngeal papillomatosis, laryngeal neoplasm, tumorigenic transformations

DOI

10.17219 /acem/67461

Copyright

Copyright by Author(s)

This is an article distributed under the terms of the

Creative Commons Attribution Non-Commercial License

(http://creativecommons.org/licenses/by-nc-nd/4.0/) 
Various studies conducted over the last years have shown a correlation between human papillomavirus (HPV) infection and the carcinogenesis process. The virus may cause neoplastic lesions, especially in the mucous membrane of the cervix, but also in other anatomic sites. The most important parts of the body toward which the virus shows the highest invasiveness include the reproductive tract, skin, as well as oropharynx and larynx. ${ }^{1}$ With the use of various molecular biology methods, one can detect the DNA of HPV in benign papillomatosis, in carcinoma verrucosum and malignant lesions in carcinoma planoepitheliale of the larynx. ${ }^{2}$ However, the virus's role in the development of laryngeal cancer has not yet been fully elucidated. The data is usually acquired from retrospective studies, which are based on formalin-fixed and paraffin-embedded material. Moreover, research is conducted on small groups often counting less than 100 patients. ${ }^{3}$ The aim of the study was to summarize the current state of knowledge regarding the presence of the HPV virus in the larynx as well as its participation in malignant transformation.

\section{The role of HPV in oncogenic transformation}

\section{Virus biology}

HPV taxonomically belongs to Papillomaviridae (previously Papovaviridae) family. HPV, however, infects skin squamous epithelial cells and mucous membranes in humans. Papillomaviruses diameter is $55 \mathrm{~nm}$, they do not have lipid envelope and their genome is protected by protein capsid of icosahedral symmetry that is built out of L1 protein $(55 \mathrm{kDa})$ in $80 \%$ and of L2 protein $(70 \mathrm{kDa})$ in $20 \%{ }^{4-7}$ There are about 150 different types of HPV, which are well characterized. ${ }^{8}$ L1 capsid protein coding sequence has to differ in at least $10 \%$ in each newly identified virion in order to classify it as a new type of HPV virus., ${ }^{4} 8$ The development of molecular biology techniques contributed to the rapid isolation and identification of new HPV types. Since 2004, it has been possible to identify about 30 new types of human papillomavirus. ${ }^{4}$

The genetic material of HPV is circular, double-stranded DNA molecule consisting of about 8000 bp (Fig. 1). Whole genetic information of a virus is encoded on one of the DNA strands, which is transcriptionally active. The genomic sequence of HPV contains 8 open reading frames (ORFs), which encode virus proteins. ORFs may be divided into $\mathrm{E}$ - early and $\mathrm{L}$ - late. The first of them is necessary for the replication of a virus genome. Those are 6 open reading frames encoding E1, E2, E4, E5, E6 and E7 proteins. The other 2 ORFs encode L1 and L2 capsid proteins. ${ }^{7}$ In the HPV genome, there is also a long control region (LCR), which is associated with the control of rep- lication and transcription of virus genes. It contains cis elements, into which transcription factors bind. ${ }^{8}$ Functions of HPV proteins are shown in Table 1.

HPV penetrates into the organism via micro-injuries of mucosa membrane, which allows the basal layer of the epithelium to be reached. The virus adsorbs and infects dividing cells. HPV attaches itself to the cell membrane with the use of epidermal growth factor receptors and $\alpha-6$ integrins. It may infect cells of the basal and para-basal layer of stratified squamous epithelium of oral cavity and pharynx. ${ }^{2,9,10}$ In the infected cells of the epithelium basal and para-basal layer, only E HPV genes encoding early viral proteins are expressed. However, HPV goes through a full development cycle only in differentiated keratinocytes that produce capsid proteins and make infectious progeny virions. ${ }^{11}$

\section{The mechanism of oncogenic transformation of cells}

The DNA of human papillomavirus, following its penetration into the cell, functions as an additional, autonomous molecule, so-called episomal form. In this format it is found in primarily infected and undifferentiated epithelial cells. ${ }^{12}$ During its developmental cycle in the host cell, HPV can enter into the lysogenic cycle, which means connection of virus DNA with genome of infected cell. Such integration is crucial for HPV-dependent carcinogenesis. Integration of genetic information occurs at ORF E1 and E2 site within the virus's nucleotide sequence, wherein products of those ORFs control level of expression of virus E6 and E7 oncoproteins. ${ }^{13}$ The consequence of virus DNA integration is sequence disruption, E2 deletion and/or inactivation resulting in the inhibition of gene function and an increase of expression of E6 and E7 oncogenes. ${ }^{12}$

Three of the early genes, E5, E6 and E7, are associated with cancer development. Proteins E6 and E7 cause dysregulation of a cell cycle, whereas E5 is associated with the carcinogenesis process, as it protects cells against apoptosis, participates in the inhibition of antigen presentation by virus-infected cells and disrupts communication

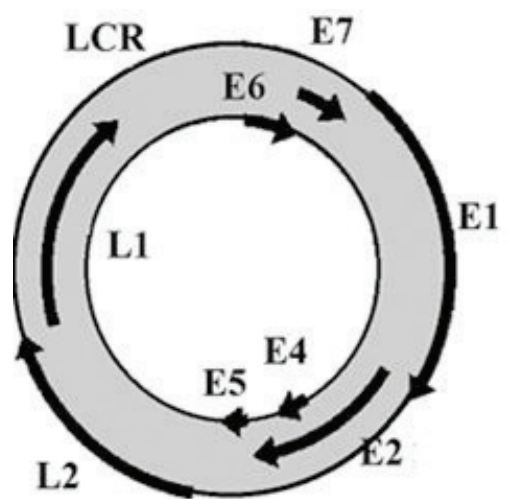

Fig. 1. Genome of human papillomavirus types 31 . $\mathrm{LCR}$ - control region, Eearly region (E1-E2, E4 - E7), $\mathrm{L}$ - late region $(\mathrm{L} 1, \mathrm{~L} 2)^{8}$ 
Table 1. Proteins function of human papillomavirus - HPV 5

\begin{tabular}{|c|c|}
\hline Protein & Function \\
\hline E1 & $\begin{array}{l}\text { - } \text { necessary for replication of viral DNA } \\
\text { - connections to the initiation site of viral DNA } \\
\text { replication } \\
\text { - forms with E2 complex, which has a helicase } \\
\text { activity }\end{array}$ \\
\hline E2 & $\begin{array}{l}\text { - it is a major transcription regulator of the virus gene } \\
\text { - combines the LCR sequences and activates or } \\
\text { represses transcription } \\
\text { - participates in the replication of viral DNA } \\
\text { - facilitates the attachment of E1 to origin of } \\
\text { replication }\end{array}$ \\
\hline E4 & $\begin{array}{l}\text { - links to keratin filaments, causing changes in the } \\
\text { keratinocytes } \\
\text { - facilitates the submission of virus particles and } \\
\text { release them during keratosis } \\
\text { - expressed mainly in the late stage of the virus cycle } \\
\text { in differentiated keratinocytes } \\
\text { - causes cell arrest at the interface of the G } 2 \text { / M in } \\
\text { the differentiated keratinocytes }\end{array}$ \\
\hline E5 & $\begin{array}{l}\text { - induces uncontrolled cell proliferation } \\
\text { - inhibits apoptosis } \\
\text { - disrupts intercellular exchange } \\
\text { - activates receptors for growth factors such as EGFR }\end{array}$ \\
\hline E6 & $\begin{array}{l}\text { - induces DNA synthesis } \\
\text { - causes the activation of telomerase } \\
\text { (immortalization of cells) } \\
\text { - prevents cell differentiation } \\
\text { - interacts with the four classes of cellular proteins } \\
\text { including: transcriptional co-activators, proteins } \\
\text { associated with the polarity of the cell, tumor } \\
\text { suppressor proteins (mainly p53) and apoptosis } \\
\text { inducers, factors involved in the replication and } \\
\text { repair of DNA }\end{array}$ \\
\hline E7 & $\begin{array}{l}\text { - induces uncontrolled cell proliferation } \\
\text { - interacts with the tumor suppressors (especially Rb) }\end{array}$ \\
\hline L1 & $\begin{array}{l}\text { - the major capsid protein } \\
\text { - reacts with cell receptors (this cells that are } \\
\text { susceptible to HPV infection) }\end{array}$ \\
\hline L2 & $\begin{array}{l}\text { - additional viral capsid protein } \\
\text { - facilitates the assembling of the capsid } \\
\text { - it may react with DNA and cellular receptors }\end{array}$ \\
\hline
\end{tabular}

between cells. ${ }^{7,14}$ HPV-infected epithelium is the only site of expression of this protein, which is not observed following the development of neoplastic lesion. The most accepted model of E5 contribution into carcinogenesis is endocytic ATPase inhibition resulting in the prevention of endocytes acidification. It leads to abnormal signaling pathways of epidermal growth factor receptors (EGFRs) endocytic exchange. ${ }^{14}$ E5 participates also in EGFR activation. Overexpression of this receptor in laryngeal cancer is a prognostic factor of tumor aggressiveness and invasiveness. EGFR increase is observed in keratinocytes and cells of laryngeal papillomas infected with HPV. It is believed that viral E5 protein may have an impact on the increased EGFR expression in cells. However, an increase in the number of receptors may result from E6 and E7 oncoprotein-dependent mechanism, which causes the transcription of a certain group of genes to be activated..$^{10}$ An additional, newly discovered function of E5 is cell fusion triggering. Studies indicate that cell fusion may play an important role in neoplastic transformation of cells. Other viruses, which, similarly to HPV, show cell fusion and are related to cancers, are: $\mathrm{HBV}, \mathrm{HCV}$ and Epstein-Barr. ${ }^{14,15}$

The E6 protein of these high-risk viruses is also involved in a multistep process of neoplastic transformation of cells. It reacts with various cell proteins involved in apoptosis, transcription regulation, the maintenance of chromosomal stability, epithelium organization, differentiation, adhesion, polarization, and the control of cell proliferation. ${ }^{16}$ Moreover, E6 oncoprotein causes an increase of hypoxia-inducible factor-1 $\alpha$ (HIF-1 $\alpha)$ and VEGF expression, which may be important in the angiogenesis process. $^{17}$

The best-known mechanism involving E6 is ubiquitindependent degradation of p53 suppressor protein. ${ }^{18} \mathrm{P} 53$ is a transcription factor, which plays many important cellular functions, such as cell cycle regulation, DNA-repair activation and induction of apoptosis. The expression level of this protein in normal cells is low; however, it increases in response to DNA damage and viral infections. ${ }^{11,18}$ E6 oncoprotein causes the abolition of 553 protein activity, consequences of which may be impaired regulation of cell proliferation (facilitation of cell division), frequent occurrence of spontaneous mutations and the stabilization of chromosomal instabilities. ${ }^{19}$ In normal cells, p53 suppressor protein degradation occurs with the participation, inter alia, of Mdm2 ligase. In virus-infected cells proteolysis depends on E6 oncoprotein, which integrates with E6AP ligase. Both proteins form stable complex into which p53 joins, thus enabling its degradation. The effectiveness of p53 degradation depends on the strength of association of suppressor protein, E6 oncoprotein and E6AP ligase. This process depends on the type of virus that has infected the cell, because there are differences in binding both p53 and E6AP ligase between high and low risk HPV. E6 HPV 16 and 18 proteins bind stronger in comparison with HPV 11. 19,20

E6 oncoprotein influences also other cellular mechanisms. p53 deregulation is one of the possible methods for preventing apoptosis of the infected cell. E6 may also destroy other pro-apoptotic factors such as Bak protein, fast-associated death domain protein (FADD) and procaspase-8. Inhibition of programmed cell death may also occur through NF-k $\beta$ transcription factor activation leading to the increase of expression of inhibitor of apoptosis 2 (IAP-2). ${ }^{19} \mathrm{E} 6$ associates also with tumor necrosis factor receptor 1 (TNF R1). ${ }^{16}$ Apoptosis may be also inhibited by E7 oncoprotein, which blocks expression of pro-apoptotic factor Mcl-1. ${ }^{21}$

Another feature of E6 protein important for carcinogenesis is its ability to immortalize the infected cell. Host cells immortalization by high-risk HPV is possible thanks to telomerase activation. In normal cells this enzyme is inactive. Increased telomerase activity was shown in can- 
cer cells. ${ }^{22}$ E6 HPV 16 protein affects the activity of this enzyme in a number of ways. One of them is an increase of the expression of hTERT gene, the product of which is enzyme catalytic subunit. E6 and E6AP ligase complex affects the level of expression of this gene. E6 may also interact with c-Myc or other transcription factor located at the hTERT promoter, for example with Sp1. Another way is the degradation of NFX1 -91, which is hTERT gene repressor. ${ }^{17}$

High-risk human papillomavirus E6 oncoprotein has also additional functions due to its ability of association and degradation of proteins that have characteristic PDZ domain. They are responsible, inter alia, for transcription regulation, cell polarity, as well as for intercellular signaling. The group of proteins that associate with E6 oncoprotein includes human homologs of DLg and Scrib suppressor proteins, MUPP1, MAGI 1-3, PTPN13 phosphatase and PATG. ${ }^{17,19}$

The most important mechanism impairing cell cycle, involving the E7 protein, is the association and degradation of proteins from retinoblastoma family $(\mathrm{pRb})$ and related p107 and p130. pRb protein binding by E7 releases transcription factor from E2F family and activates the transcription of certain group of genes, which regulate cellular proliferation. This causes a disruption of the cell cycle, promotion into $\mathrm{S}$ phase of a cycle and stimulation of amplification of its genes, as well as virus genes. ${ }^{11}$ On the other hand, E2F influences the increase of the expression of proteins, such as, e.g. p16 and MCM 7. In HPVdependent laryngeal cancer increased level of cyclin D1 is observed, which is also associated with pRB pathway. ${ }^{23,24}$ Another method by which the virus promotes the amplification of its own genes is the association of E7 with cyclin-dependent kinase inhibitors (CKI), such as, e.g. p21 or $\mathrm{p} 27 .{ }^{20}$ Interactions of E5, E6 and E7 proteins and other factors are shown in Fig. 2.

Fig. 2. E5, E6 and E7 proteins overexpression of high-risk HPV and their interaction with different host cells factors ${ }^{16}$

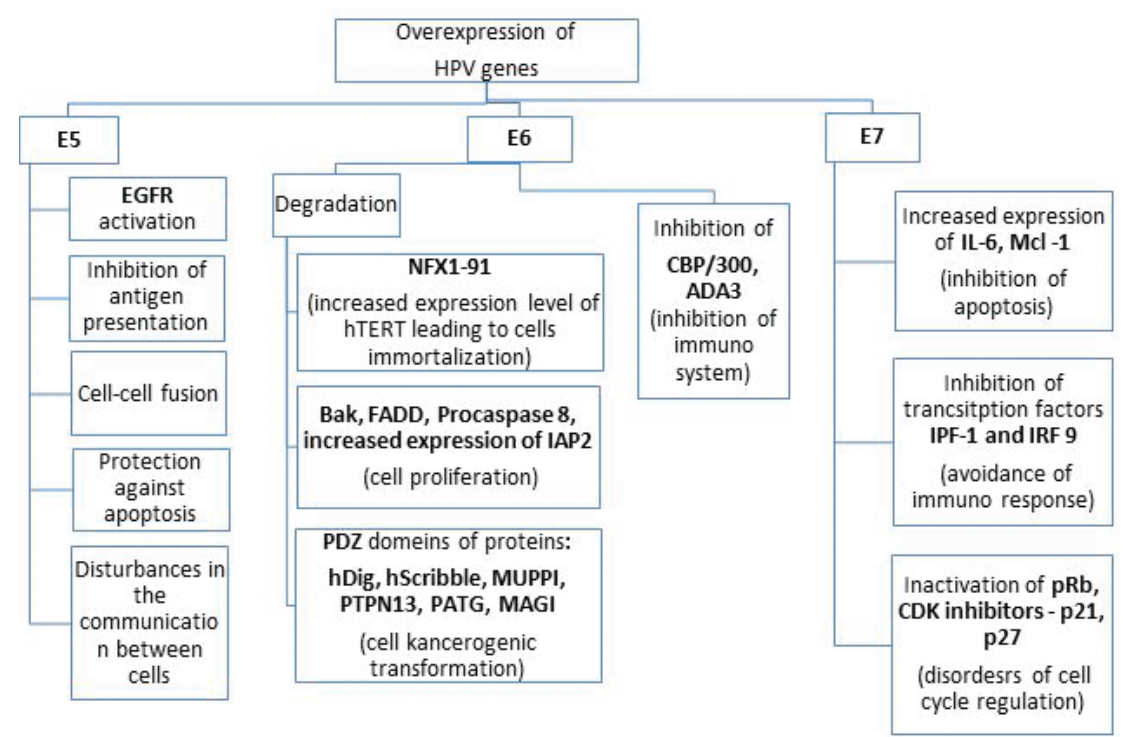

\section{Virus detection}

There are many methods of HPV detection in abnormal tissues collected from the head and neck region, such as the analysis of tissue material (bioptats), cellular material (cytology - washings, brush tip swabs) and serum from patients. ${ }^{25}$ Certain morphological features of HPV infection are visible in microscopic images. Infected cells look like koilocytes with a characteristic paranuclear clear zone, the so-called halo, as well as a clearly marked cell membrane, which results from HPV propagation. The cell nucleus is also morphologically changed; it is small and deformed, with abnormal staining. The presence of kolicytes and extensive vasculature is called "koliocytsis florida" and it coexists mainly in low-risk HPV infections -6 and $11 .{ }^{26}$

However, only molecular diagnostic techniques provide a definitive diagnosis of HPV infection. The most frequently used methods include polymerase chain reaction (PCR), in situ hybridization (ISH) and immunohistochemical method (IHC) evaluating expression level of p16 protein. The most frequently used method in molecular biology is PCR technique, however it is not routinely used in each laboratory. It has some constrains as it is believed to be sometimes too sensitive and prone to contamination. ${ }^{27}$ The most of PCR reactions is carried out with the use of a pair of primers GP5+/GP6+, MY09/11 and SPF10. It allows for the detection of a broad range of different types of HPV. The set of GP 5/6 primers was initially designed in order to detect HPV 6, 11, 16, 18, 31 33, but later it was shown that they may be used for the detection of up to 27 types of HPV. All of them target highly conservative DNA fragment of HPV L1 gene and are able to detect a number of HPV types during one PCR reaction.

The sensitivity of the reaction is increased by an additional nested-PCR with the set of MY09-MY11 primers, followed by GP 5+/6+. However, one should bear in mind the fact that in some cases the result of PCR reaction with the use of the abovementioned primers may be false negative. This is because of the fact that L1 gene-containing a part of HPV genome might be lost during the integration of viral genetic material with the genome of the host cell. For this reason PCR methods have been developed that allow the amplification of E6 and E7 gene-containing fragments of the genome. Both of those genes contain highly-conservative regions and should be taken into account in the case of PCR reactions with false negative results. ${ }^{28}$

The in situ hybridization method allows for the detection of HPV localization in the nuclei of infected cells, es- 
Fig. 3. A positive nuclear reaction immunohistochemistry (IHC) performed using an antibody directed against the protein p16 on paraffin sections of laryngeal papillomas (A) and IHC positive cytoplasmic reaction in squamous cell carcinoma of the larynx (B). In both cases revealed the presence of HPV also using the PCR method

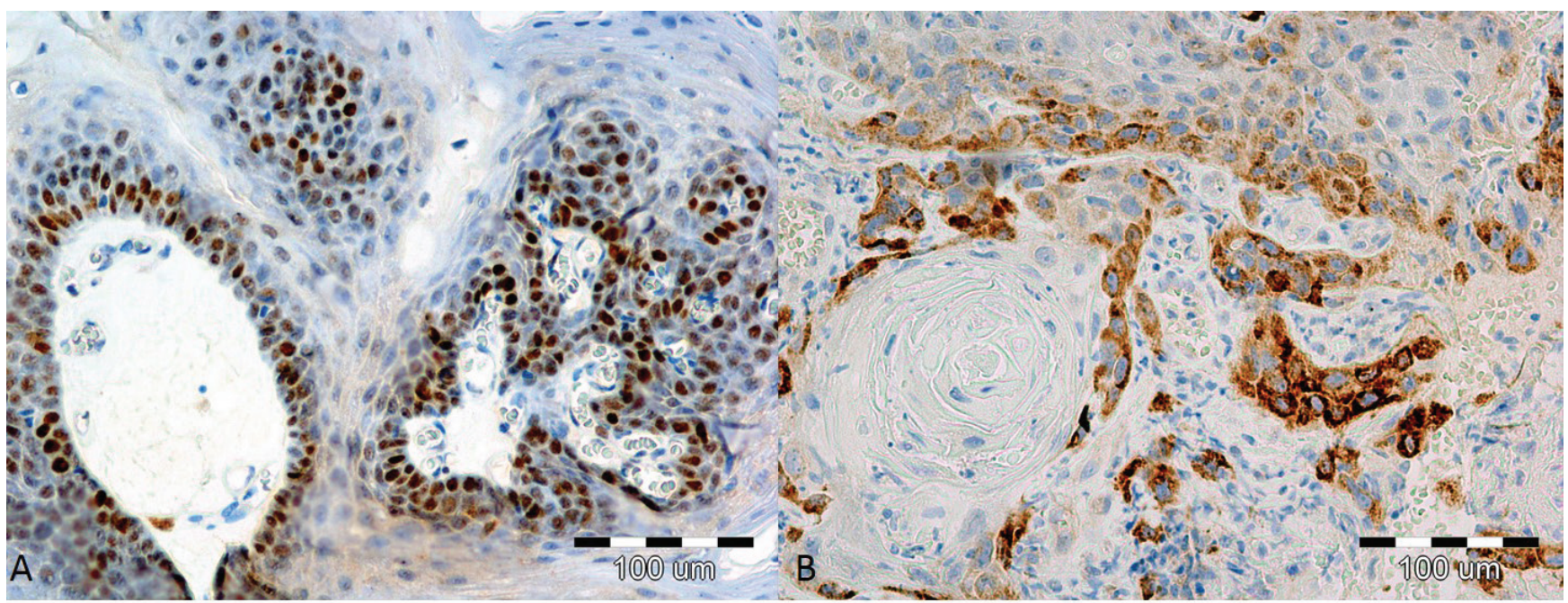

pecially cancerous ones. However, ISH is characterized by the limited sensitivity and higher costs in comparison with traditional IHC method. For in situ hybridization reaction, chromogen or fluorine-labelled probes are used, which allow for the detection of a broad range of HPV types, especially in paraffin-sections. ISH allows for the detection of HPV's DNA integrated with the genome of the host cell, which is the case for cancer cells. Therefore, it may be a tool for the detection of mucous membrane cells cancerous transformation process at its early stages.

Immunohistochemical technique (IHC) is a method commonly used in the diagnostic laboratories. In particular, the use of IHC for the evaluation of p16 expression level is recognized as a surrogate marker used in the screening for transcriptionally active infections (Fig. 3). ${ }^{27,28}$

It is believed that high-risk HPV E7 oncoprotein associates with factors from retinoblastoma family $(\mathrm{Rb})$, which causes E2F transcription factor release from the complex. This factor activates transcription of multiple genes, including p16-INK4a and proteins from minichromosome maintenance proteins (MCMs) family. The consequence of this reaction is an increase of p16 and MCM expression in cells infected with high-risk HPV. For this reason p16 and MCM proteins could be supportive marker indicating HPV infection. ${ }^{24,29}$ Moreover, recent studies have shown that p16 expression correlates with better survival of patients with squamous cell head and neck cancer. ${ }^{27}$

\section{HPV in laryngeal pre-neoplastic and neoplastic lesions}

Among various types of human papillomavirus, there are about 40 types, which attack genitals and are present in biopsy material from uterine cervix cancers. The DNA of the same virus types is found in nearly $20 \%$ of upper respiratory track cancers. Currently, it is believed that exactly those HPV types may contribute to the immortalization and oncogenic transformation of the infected cells. Those viruses are considered as high-risk HPV. The most representative among this group are HPV types: 16 , $18,31,33,39,45,52,58$ and $69 .{ }^{19}$ The other group of viruses is low-risk HPVs, which are associated with the aetiology of, e.g. cutaneous warts, condyloma acuminate or recurrent laryngeal papillomatosis. This group comprises HPV 6, 11, 42, 43 and 44. ${ }^{11,19}$ Infection with oncogenic types of HPV is one of the conditions required for the development of cervical cancer. Virus DNA is found in $99 \%$ of the analyzed neoplastic lesions of uterine cervix. ${ }^{19}$ HPV DNA is found in the lower percent of analyzed laryngeal squamous cell carcinoma cases (from 7 to 59\%) in comparison to uterine cervix cancers. HPV 16 accounts for $74 \%$ and HPV 18 for $16 \%$ of types detected in this cancer. In laryngeal neoplastic lesions it is, similarly to uterine cervix cancer, the most frequently occurring type of human papillomavirus. ${ }^{5}$

HPV infection is a factor enabling the neoplastic transformation of epithelial cells. Usually other stimuli are present but they are not necessary for cancer development. ${ }^{30}$ In the case of laryngeal cancers, such factors include smoking and consuming excessive amounts of alcohol, incorrect diet, as well as gastroesophageal reflux disease (GERD) and laryngopharyngeal reflux (LPR). ${ }^{31-33}$ The occurrence of permanent genetic changes is also important for cancer development, leading to the impairment in the control of cell division, growth and differentiation. ${ }^{11,20}$

Laryngeal epithelium is also susceptible to HPV infection. Transmission route for the virus are most often sexual contacts. In the case of the head and neck, oral contact with infected genitals is an important way of infection. It has been shown that there is a direct dependency between 
an infection of genital and oral cavity. ${ }^{34,35}$ Georgiewa S. and Iordanov $\mathrm{V}$. described the case of a woman found with the presence of HPV 16. The woman was also diagnosed with 3 cancers of uterine cervix, external genital organs and larynx, which were developing simultaneously. Researchers considered all of the cancers to be related to the some, HPV16, types of the virus. ${ }^{36}$ Children can be also infected with the virus from the mother during labor. Perinatal transmission of the infection with oncogenic types of human papillomavirus occurs not only in the case of vaginal birth. Vertical transmission is a result of contact of a fetus with HPV infected cervical cells. It was observed that a mother's higher viral load is an important and determining factor in the transmission to their infants. HPV infections are rather rare during pregnancy and labor complications as well, and they concern less than $1 \%$ of new born children. Additionally, the HPV virus was also detected in samples from breast milk. There is a theoretical possibility to infect a child via breast-feeding. ${ }^{37,38}$

Papillomas usually develop at the interface between stratified squamous epithelium and multi-row respiratory epithelium, but they may occur also few centimeters away from this area. In the laryngeal respiratory epithelium, HPV induces proliferation of reserve cells with stem potential. This process may lead to the thickening of squamous epithelium layers and to the development of papilloma, as well as to metaplasia outbreaks. ${ }^{2}$

\section{HPV in laryngeal papillomas}

Laryngeal papillomas are benign epithelial lesions. This term is used to describe 2 diseases that differ in clinical course, etiology and prognosis. One of the diseases is an adult type and the second is children type of laryngeal papillomatosis. HPV type 6 and 11 infection is an etiological agent of both types of laryngeal papillomas. The first of abovementioned types of virus is more frequent among adult patients. Vocal folds are the most common place for the emergence of lesions. Laryngeal papillomas found in children are characterized by the disease peak in the $5^{\text {th }}$ year of life, while the adult type papillomas - between $20-30^{\text {th }}$ year of life. In adulthood the diseases are more often found in men, while no such correlation was found in children. ${ }^{1,39}$

Malignant transformation of laryngeal papillomas occurs very rarely. Many studies have shown that $1-7 \%$ of laryngeal papillomas transform into squamous cell carcinoma. ${ }^{3,39}$ Although HPV is an essential factor for the establishment of papillomas, an infection alone is not sufficient for their development. The presence of HPV has been found also in normal cells of laryngeal epithelium. ${ }^{40}$ The most researchers in their reports have shown that HPV11 type is more aggressive and causes severe papillary lesions, especially in children. ${ }^{41}$ The mechanism of this transformation is not yet fully known and explained.
Some of the authors believe that both integration of HPV's DNA with host cell DNA, as well as p53 gene mutation is necessary for oncogenic transformation. ${ }^{19}$ It is also suggested that low-risk HPV infections (HPV 6 and 11) may cause oncogenic transformation in combination with other co-factors, such as nicotine and alcohol. However, some studies have shown the integration of HPV 6 DNA with host cell's DNA in case of tonsil cancer, which is similar to the infection with high-risk HPV. ${ }^{26}$ The host's immune response is also an important factor for malignant transformation. HPV-infected cancer cells may also evade immunological response. E7 protein associates with interferon regulation factor IRF1 and IRF9 and therefore leads to their inactivation and blockage of interferon alpha (INF $\alpha$ ) signaling pathway. ${ }^{42}$

Papillomas, although they are non-malignant lesions, may cause airway obstruction, thus posing a risk for life. They require multiple hospitalizations, surgical procedures and pharmacological treatment. The main method of treatment of laryngeal papillomatosis is surgical removal using a $\mathrm{CO}_{2}$ laser. The children are also treated by alfainterferon in the case of an aggressive course of the disease. The results of therapy are not satisfactory, because the disease often recurs. ${ }^{39}$ An interesting phenomenon is the fact that for some patients infected with HPV 6 and 11 , immune responses have been shown, which encourages the maintenance of chronic HPV infection. A characteristic feature of the diseases caused by HPV, such as recurrent papillomatosis of upper respiratory track, skin papillomas or uterine cervix cancer, is clear lack of HPVspecific cytotoxic T lymphocytes (CTL) and Th1 lymphocytes releasing inflammatory cytokines, such as IFN- $\gamma$, IL- 2 and TNF- $\alpha{ }^{43}$

\section{HPV in laryngeal cancer}

Head and neck cancer is the fifth most common cancer in the world. ${ }^{44}$ Every year, there are more than 640,000 cases of this cancer reported and it causes over 350,000 deaths. ${ }^{28}$ Squamous cell carcinoma is the most frequent type of neoplastic lesions affecting the head and neck area. ${ }^{34}$ On the other hand, laryngeal squamous cell cancer is the most common among head and neck neoplasms and it accounts for about $60 \%$ of all cancers in the head and neck area. ${ }^{4}$

HPV infections occur often in the larynx. In a vast majority of cases, the virus is related to benign, single papillas or cancers. In those lesions abnormalities in maturation and differentiation of epithelial cells occur, which is characteristic for HPV infections. Once cells of basal layer of epithelium are infected, HPV may enter a latency stage and give no symptoms. Then no histological changes in epithelium are observed. Such a situation may last for several months or even years. However, persistent HPV infection may cause neoplastic transformation of cells. ${ }^{44}$ 
Table 2. Prevalence of HPV in verrucous carcinoma²

\begin{tabular}{|l|c|c|c|c|}
\hline \multicolumn{1}{|c|}{ Source } & $\begin{array}{c}\text { Publication } \\
\text { date }\end{array}$ & Sample size & $\begin{array}{c}\text { Detection } \\
\text { technique }\end{array}$ & HPV + (\%) \\
\hline Abramson, et al. & 1985 & 5 & IHC, ISH & $5(100 \%)$ \\
\hline Kasperbauer, et al. & 1993 & 20 & $\begin{array}{c}\text { PCR } \\
\text { ISH }\end{array}$ & $\begin{array}{c}17(85 \%) \\
0(0 \%)\end{array}$ \\
\hline Fliss, et al. & 1994 & 29 & PCR & $13(45 \%)$ \\
\hline Lopez-Amado, et al. & 1996 & 10 & PCR & $4(40 \%)$ \\
\hline
\end{tabular}

in cancerous lesion of larynx varies depending on the procedure applied for samples collection and viral DNA detection method. High variance in the frequency of HPV detection is observed even among results obtained with the use of PCR reaction. It varies between 3 and $85 \%$. The differences depend on primers used for the reaction, genomic localization and the length of the product amplified by PCR, conditions of the reac-

Laryngeal cancer may result from late complication of squamous cell papilloma (SCP), although most of those malignant changes develop without papillomas. Generally, squamous cells laryngeal cancer development begins based on dysplastic changes, intraepithelial neoplasia and pre-invasive cancer (carcinoma in situ) occurring within epithelium of mucosa membrane lining the organ. ${ }^{1}$

The clinical importance of HPV infection and its association with head and neck cancers development is well documented and confirmed by multiple studies. ${ }^{45} \mathrm{~W}$ ithin this group of cancers, oropharyngealand laryngeal carcinomas are the most dependent on HPV. However, HPV involvement in laryngeal cancer etiology has not yet been fully evaluated. ${ }^{2,46}$ Many studies related to this subject have been conducted within the past decade. The presence of HPV

Table 3. Selected research on the prevalence of HPV in LSCC 2

\begin{tabular}{|c|c|c|c|c|c|}
\hline Source & $\begin{array}{l}\text { Publication } \\
\text { date }\end{array}$ & $\begin{array}{l}\text { Sample } \\
\text { size }\end{array}$ & $\begin{array}{l}\text { Detection } \\
\text { technique }\end{array}$ & $\mathrm{HPV}+(\%)$ & Genotypes \\
\hline Syrjänen, et al. & 1987 & 116 & ISH & $12.9 \%$ & 11,16 \\
\hline Salam, et al. & 1995 & 87 & $\begin{array}{l}\text { genotyping } \\
\text { RFLP }\end{array}$ & $22.2 \%$ & $6,11,16$ \\
\hline Fouret, et al. & 1997 & 103 & PCR & $6.8 \%$ & 16 \\
\hline Ma, et al. & 1998 & 102 & $\begin{array}{l}\text { genotyping } \\
\text { southern } \\
\text { blot } \\
\text { hybridization }\end{array}$ & $58.8 \%$ & $\begin{array}{c}6,11,16 \\
18,33\end{array}$ \\
\hline Gorgoulis, et al. & 1999 & 91 & $\begin{array}{l}\text { Genotyping } \\
\text { Nested PCR }\end{array}$ & $21 \%$ & $6,16,18,33$ \\
\hline Gillison, et al. & 2000 & 86 & ISH & $19 \%$ & 16 \\
\hline Almadori, et al. & 2001 & 42 & $P C R$ & $35.7 \%$ & 16,18 \\
\hline de Oliveira, et al. & 2006 & 110 & $\begin{array}{l}\text { multiplex } \\
\text { PCR }\end{array}$ & $37.3 \%$ & 16,18 \\
\hline Gungor, et al. & 2007 & 95 & $\begin{array}{l}\text { genotyping } \\
\text { multiplex } \\
\text { PCR }\end{array}$ & $7.4 \%$ & $6,11,16$ \\
\hline Applebaum, et al. & 2007 & 93 & ELISA & $13 \%$ & - \\
\hline Koskinen, et al. & 2007 & 108 & $P C R$ & $3,3 \%$ & $6,11,16,33$ \\
\hline Morshed, et al. & 2008 & 93 & $\begin{array}{l}\text { genotyping } \\
\text { INNO-LIPA }\end{array}$ & $35.5 \%$ & $16,18,33$ \\
\hline Fakhry, et al. & 2008 & - & $\begin{array}{l}\text { PCR } \\
\text { ISH }\end{array}$ & $40 \%$ & $16,33,35$ \\
\hline
\end{tabular}

tion and false positive results obtained due to the sample contamination with viral particle. ${ }^{46}$

Squamous cell laryngeal cancer accounts for more than $90 \%$ of malignant lesions of this organ. A high prevalence of this virus among such cancers is noted in verrucous carcinoma. It is a rare variant of low malignancy, highly differentiated LSCC. ${ }^{3,47}$ In verrucous carcinoma, the dominant types of HPV are 16, 18, 11 and 6. Most of the studies on the presence of the virus in this type of cancer were carried out in the nineties. They revealed a fairly strong relationship between HPV and this rare cancer; however, the research was based on small study groups. The results of the studies are summarized in Table 2 . In verrucous carcinoma, the relationship between the presence of HPV and a high stage of cancer were observed. However, no correlation was reported between the presence of HPV in cancer and the age of patients, tumor localization or response to radiotherapy. ${ }^{2}$

Nevertheless, most of the research is carried out on typical laryngeal squamous cell carcinoma. Kreimer et al. showed meta-analysis of 5,046 cases of head and neck cancers from all over the world, 1,435 of which were laryngeal cancers tested for the presence of human papillomavirus with the use of PCR detection. In 35 publications related to the cancer of larynx, HPV was shown in $24 \%$ of cases. Kreimer et al. paid particular attention to the geographical localization of the conducted studies and they confirmed that the prevalence of HPV occurrence in cases of head and neck cancers depends on the region of the world inhabited by the patients. The HPV prevalence in case of larynx infection was highest in Asia and accounted for $38.2 \%$ of squamous cell cancers. ${ }^{47}$

Based on the research conducted over recent years, one can conclude 
that there is a high probability of HPV 16 (and less frequently detected HPV 18, 31 and 33) contribution to the etiology of laryngeal cancers - at least a certain group of them. Table 3 shows some of the results of research conducted on groups of about one hundred patients.

The overview of clinical and epidemiological data demonstrates the presence of 2 subtypes of head and neck cancers. One of them is cancer depending on the exposition to tobacco. On the contrary, the other group of neoplasms develops in association with HPV infection. In science, the idea of HPV-dependent and HPV-independent cancer is commonly accepted..$^{1}$ Cancers associated with viral infections show some common features. In comparison to HPV-independent group, they have less DNA mutations and single, small chromosomal aberrations. They are characterized by long promotion period, resulting from latent, persistent infection. ${ }^{34}$ In this group of laryngeal cancers, contribution of addictions considered to be the most important risk factors, i.e. smoking and alcohol consumption, is significantly lower. ${ }^{47}$ Also, HPV-dependent head and neck cancers have less severe disease course and are characterized by longer patient survival. ${ }^{34}$ Moreover, Gillson and co-workers showed that the risk of death was significantly decreased (from 60 up to $80 \%$ ) in patients with HPV infected oropharyngeal squamous cell cancers in comparison with control group. Schwarz et al. also confirmed longer survival in case of HPV infected patients with oral squamous cell cancer. The better response for radiotherapy and chemotherapy was described by a few researchers. This better response may be the reason for lower mortality in patients with HPV infections. Currently, knowledge about the reasons for better response to the treatment of patients with HPV related laryngeal cancer is poor. Further research on this subject is needed. Isayeva et al. published data concerning the prognostic significance of HPV in squamous cancer of the oral cavity, larynx, sinonasal tract and nasopharynx. They found no association between HPV infections and treatment outcome. ${ }^{48-51}$

It seems important to also raise the issue of preventive vaccines against this virus. Currently, there are 2 types of commercially available vaccines, the bivalent (targeted to HPV 16 and HPV18) one and the tetravalent (against HPV 16, 18, 11 and 6) one. The vaccines were designed to induce the production of antibodies against the viral protein and do not have viral DNA. Thus far, only girls have been included in the preventive vaccines plan due to high virus detection in mucosal membrane of uterine cervix in various pre-cancerous and cancerous lesions. According to The Polish Gynecological Society, girls aged 12-13 years, who have had no sexual contact, may be vaccinated. In view of many studies regarding the relationship between HPV infection and head and neck cancers there are suggestions that, perhaps, boys also should be included in vaccination schedules.

\section{Summary}

The role of human papillomavirus in the etiology of pre-cancer laryngeal lesions and larynx cancer is unquestionable. HPV is one of the laryngeal cancer risk factors. Laryngeal cancer associated with viral infections shows a long promotion period, resulting from a latent, persistent infection. The contribution of addictions in the group of laryngeal cancers with HPV infections, i.e. smoking and alcohol consumption, is significantly lower. HPV-dependent head and neck cancers have less severe course of the disease and are characterized by longer patient survival. There is little research on this question in laryngeal cancer. However, according to current knowledge, there is no data suggesting that HPV related laryngeal cancer is milder and leads to higher survival rates. Further research on this subject is needed.

\section{References}

1. Syrjänen S. Human papillomavirus (HPV) in head and neck cancer. J Clin Virol. 2005;32:59-66.

2. Torrente MC, Rodrigo JP, Haigentz MJ, et al. Human papillomavirus infections in laryngeal cancer. Head Neck. 2011;33:581-586.

3. Aaltonen LM, Rihkanen $\mathrm{H}$, Vaheri A. Human papillomavirus in larynx. Laryngoscope. 2002;112:700-707.

4. Kovanda A, Kocjan BJ, Potočnik M, Poljak M. Characterization of a novel cutaneous human papillomavirus genotype HPV-125. PLoS One. 2011;6:e22414.

5. IARC Monographs on the evaluation of carcinogenic risks to humans; v. 90 Human papillomaviruses. WHO, France, Lyon 2007, 66-75.

6. Burk RD, Chen Z, Harari A, et al. Classification and nomenclature system for human Alphapapillomavirus variants: General features, nucleotide landmarks and assignment of HPV6 and HPV11 isolates to variant lineages. Acta Dermatovenerol Alp Panonica Adriat. 2011;20:113-123.

7. Kabsch $\mathrm{K}$ and Alonso A. The human papillomavirus type $16 \mathrm{E} 5$ protein impairs TRAIL- and FasL-mediated apoptosis in HaCaT cells by different mechanisms. J Virol. 2002;76:12162-12172.

8. Fehrmann F and Laimonis AL. Human papillomaviruses: Targeting differentiating epithelial cells for malignant transformation. Oncogene. 2003;22:5201-5207.

9. Almadori G, Cadoni G, Cattani P, et al. Human papillomavirus infection and epidermal growth factor receptor expression in primary laryngeal squamous cell carcinoma. Clin Cancer Res. 2001;7:3988-3993.

10. Campisi G, Panzarella V, Giuliani M, et al. Human papillomavirus: Its identity and controversial role in oral oncogenesis, premalignant and malignant lesions (review). Int J Oncology. 2007;30:813-823.

11. Morshed K. Udział wirusa brodawczaka ludzkiego (HPV) w etiopatogenezie nowotworów glowy i szyi. Otolaryngologia. 2004;3:91-96.

12. Szostek S, Zawilińska B, Klimek M, Wójcik K, Koprynia M, KoszVnenchak M. Różnicowanie postaci zintegrowanej i episomalnej DNA HPV-16 metodą real-time PCR w wydzielinie szyjki macicy kobiet z rozpoznaną śródnabłonkową neoplazją i rakiem szyjki macicy. Ginekol Pol. 2011;82:441-445.

13. Ho CM, Lee $B H$, Chang SF, et al. Integration of human papillomavirus correlates with high levels of viral oncogene transcripts in cervical carcinogenesis. Virus Res. 2011;161:124-130.

14. Hu L, Ceresa BP. Characterization of the plasma membrane localization and orientation of HPV16 E5 for cell-cell fusion. Virology. 2009;393:135-143.

15. Gao P, Zheng J. High-risk HPV E5-induced cell fusion: A critical initiating event in the early stage of HPV-associated cervical cancer. J Virol. 2010;7:238.

16. Tungteakkhun SS, Duerksen-Hughes PJ. Cellular binding partners of the human papillomavirus E6 protein. Arch Virol. 2008;153: 397-408. 
17. Zhang E, Yand Tang XD. Human Papillomavirus Type 16/18 Oncoproteins: Potential therapeutic targets in non-smoking associated lung cancer. Asian Pacific J Cancer Prev. 2012;13:5363-5369.

18. Scheffner M, Whitaker NJ. Human papillomavirus-induced carcinogenesis and the ubiquitin-proteasome system. Semin Cancer Biol. 2003;13:59-67.

19. Ciesielska U, Nowińska K, Podhorska-Okołów M, Dzięgiel P. The role of human papillomavirus (HPV) in the process of malignant transformation in cervix epithelial cells and importance of vaccination against this virus. Adv Clin Exp Med. 2012;21:235-244.

20. Stasikowska-Kanicka O, Wągrowska-Danilewicz M, Danilewicz $M$. Effect of human papillomavirus on cell cycle-related proteins p16INK4A, p21waf1/cip1, p53 and cyclin D1 in sinonasal inverted papilloma and laryngeal carcinoma. An in situ hybridization study. Folia Histochem Cytobiol. 2011;49:34-40.

21. Cheng YW, Lee H, Shiau MY, Wu TC, Huang TT, Chang YH. Human papillomavirus type 16/18 up-regulates the expression of interleukin- 6 and antiapoptotic Mcl-1 in non-small cell lung cancer. Clin Cancer Res. 2008;14:4705-4712.

22. Pendino F, Tarkanyi I, Dudognon C, et al. Telomeres and telomerase; Pharmacological targets for new anticancer strategies? Curr Cancer Drug Targets. 2006;6:147-180.

23. Almadori G, Galli J, Cadoni G, Bussu F, Maurizi M. Human papillomavirus infection and cyclin D1 gene amplification in laryngeal squamous cell carcinoma: biologic function and clinical significance. Head Neck. 2002;24:597-604.

24. Shigehara K, Sasagawa T, Kawaguchi S, et al. Etiologic role of human papillomavirus infection in bladder carcinoma. Cancer. 2011;117: 2067-2076.

25. Rutkowski T, Składowski K. Wpływ wirusa brodawczaka ludzkiego (HPV) na powstawanie, przebieg i skuteczność leczenia raków regionu szyi głowy. Współczesna onkologia. 2009;13:233-240.

26. Więcławska M, Kukwa A, Malejczyk M, Majewski S, Borowicz K. Zakażenie wirusem brodawczaka ludzkiego (HPV) w obrębie jamy ustnej i gardła. Czas Stomat. 2005;10:689-702.

27. Jaiyeola T, Thad P. Is p16 immunohistochemistry a more cost-effective method for identification of human papilloma virus-associated head and neck squamous cell carcinoma? Ann Diagn Pathol. 2012; 16:91-99.

28. Snow $\mathrm{N}$ and Laudadio J. Human papillomavirus detection in head and necksquamous cell carcinomas. Adv Anatomic Path. 2010;17: 394-403.

29. Brake T, Connor JP, Petereit DG, Lambert PF. Comparative analysis of cervical cancer in women and in a human papillomavirustransgenic mouse model: Identification of minichromosome maintenance protein 7 as an informative biomarker for human cervical cancer. Cancer Res. 2003;63:8173-8180.

30. Pett M, Coleman N. Integration of high-risk humen papillomaviruses: A key event in cervical carcinogenesis? J Pathol. 2007;212(4):356-367.

31. Hapner ER, Wise JC. Results of a large- scale head and neck cancer screening of an at- risk population. J Voice. 2011;25:480-483.

32. Islami Fl, Tramacere I, Rota M. Alcohol drinking and laryngeal cancer: Overall and dose-risk relation - A systematic review and metaanalysis. Oral Oncol. 2010;46:802-810.

33. Lewin JS, Gillenwater AM. Characterization of larygopharyngeal reflux in patients with premaligment or early carcinomas of the larynx. Cancer. 2003;97:1010-1014.
34. Szyfter K, Wierzbicka M. Rola wirusa brodawczaka (HPV) w nowotworach głowy i szyi. Postępy w chirurgii głowy i szyi. 2008;2:41-50.

35. Flores-de la Torre C, Hernández-Hernández DM, Gallegos-Hernández JF. Human papilloma virus in patients with epidermoid head and neck carcinoma: A prognostic factor? Cir Cir. 2010:78;221-228.

36. Georgieva S, lordanov V. A woman with synchronous cervical, vaginal and laryngeal squamous cell carcinomas and positive human papillomavirus type 16; case presentation with literature review. J Buon. 2008;13:109-112.

37. Tarka A, Szczepańska M, Rokita W, Józefiak A, Kędzia W. Ocena ryzyka rozwoju przewlekłego zakażenia typami wysokoonkogennymi wirusa brodawczaka ludzkiego (HPV HR) u noworodków zakażonych w okresie perinatalnym. Ginekol Pol. 2011;82:664-669.

38. Syrjänen S. Current concepts on human papillomavirus infections in children. APMIS. 2010;118:494-509.

39. Mackiewicz-Nartowicz H, Doroszyńska-Tomczyk M, Laskowska K. Transformacja nowotworowa brodawczaków krtani u dorosłych. Otolaryngologia. 2008;7:143-147.

40. Kaczmarek J. Zmiany i stany przednowotworowe raków płaskonabłonkowych jamy ustnej i górnych dróg oddechowych. Postępy w chirurgii głowy i szyi. 2004;2:15-31.

41. Wiatrak BJ, Wiatrak DW, Broker TR, Lewis L. Recurrent respiratory papillomatosis: A longitudinal study comparing severity associated with human papilloma viral types 6 and 11 and other risk factors in a large pediatric population. Laryngoscope. 2004;114:1-23.

42. Um SJ, Rhyu JW, Kim EJ, Jeon KC, Hwang ES, Park JS. Abrogation of IRF-1 response by high-risk HPV E7 protein in vivo. Cancer Lett. 2002;179:205-212.

43. Bonagura VR, Hatam LJ, Rosenthal DW, et al. Recurrent respiratory papillomatosis: a complex defect in immune responsiveness to human papillomavirus-6 and -11. APMIS. 2010;118:455-470.

44. Rodrigo JP, García-Carracedo D, González MV, Mancebo G, Fresno MF, García-Pedrero J. Podoplanin expression in the development and progression of laryngeal squamous cell carcinomas. Mol Cancer. 2010;48:1-9.

45. Galli J, Cammarota G, Calò L, et al. The role of acid and alkaline reflux in laryngeal squamous cell carcinoma. Laryngoscope. 2002;112:1861-1865.

46. Gungor A, Cincik H, Baloglu H, Cekin E, Dogru S, Dursun E. Human papilloma virus prevalence in laryngeal squamous cell carcinoma. J Laryngol Otol. 2007;121:772-774.

47. Kreimer AR, Clifford GM, Boyle P, Franceschi S. Human papillomavirus types in head and neck squamous cell carcinomas worldwide: a systematic review. Cancer Epidemiol Biomarkers Prev. 2005;14: 467-475.

48. Gillison ML, Koch WM, Capone RB, et al. Evidence for a causal association between human papillomavirus and a subset of head and neck cancers. J Nat/ Cancer Inst. 2000;92:709-720.

49. Schwartz SR, Yueh B, McDougall JK, Daling JR, Schwartz SM. Human papillomavirus infection and survival in oral squamous cell cancer: A population-based study. Otolaryngol HeadNeck Surg. 2001;125:1-9.

50. Fakhry C, Westra WH, Li S, et al. Improved survival of patients with human papillomavirus-positive head and neck squamous cell carcinoma in a prospective clinical trial. JNCI J Natl Cancer Inst. 2008;100:261-269.

51. Isayeva T, Li Y, Maswahu D and Brandwein-Gensler M. Human papillomavirus in non-oropharyngeal head and neck cancers. A systematic literature review. Head Neck Pathol. 2012;6:104-120. 